\title{
Level of Heterozygosity and Mode of Inheritance of Variable Number of Tandem Repeat Loci in Avocado
}

\author{
Samir Mhameed and Dror Sharon \\ Department of Fruit Trees, Genetics and Breeding, Agricultural Research Organization,The Volcani \\ Center, P.O. Box 6, Bet-Dagan 50250, Israel \\ Jossi Hillel \\ Department of Genetics, Faculty of Agriculture, The Hebrew University of Jerusalem, \\ Rehovot 76100, Israel \\ Emanuel Lahav \\ Department of Fruit Trees, Agricultural Research Organization, The Volcani Center, P.O. Box 6, \\ Bet-Dagan 50250, Israel \\ Daniel Kaufman and Uri Lavi ${ }^{1}$ \\ Department of Fruit Trees, Genetics and Breeding, Agricultural Research Organization,The Volcani \\ Center, P.O. Box 6, Bet-Dagan 50250, Israel \\ Additional index words. breeding, DNA fingerprint, simple sequence repeat, VNTR markers

\begin{abstract}
To estimate heterozygosity level in the avocado (Persea americana Mill.) genome, two types of variable number of tandem repeat (VNTR) markers were used. Multilocus DNA fingerprints (DFPs) were analyzed on avocado progeny resulting from either crosses or selfing of cultivars. In five crosses, heterozygosity was $100 \%$, while in two self-pollinated families, heterozygosity was $90 \%$ and $94 \%$. Single locus, simple sequence repeat (SSR) DNA markers were analyzed by typing 59 loci on five avocado cultivars. Average heterozygosity varied from 0.50 to 0.66 , while gene diversity varied from 0.42 to 0.66 . Heterozygosity varied from $38 \%$ to $70 \%$. The percentage of fragments that exhibited Mendelian inheritance was $62.5 \%$ to $85 \%(P<0.05)$ for the DFP fragments and $85 \%$ for the SSR alleles.
\end{abstract}

Minisatellite and microsatellite markers have been found to be highly polymorphic in many species due to the presence of variable number of tandem repeat (VNTR) markers (Adato et al., 1995; Dallas, 1988; Hillel et al., 1989; Jeffreys et al., 1985a, 1985b; Lavi et al., 1991; Nurnberg et al., 1989; Nybom and Schaal, 1990; Sharon et al., 1995). DNA fingerprints (DFPs) obtained by the hybridization of digested genomic DNA with multilocus probes are useful for identifying cultivars and races (Lavi et al., 1991), genetic analyses (Kuhnlein et al., 1989), and for the search of linkage between DFP bands and genes of economic importance (Mhameed et al., 1995; Plotsky et al., 1993). The advantage of using multilocus markers over restriction fragment-length polymorphisms (RFLPs) (Furnier et al., 1990) for identification and genetic analyses stems from the high level of polymorphism and the simultaneous detection of many polymorphic loci by one or few multilocus probes. However, due to the complex analysis of multiband patterns found in multilocus markers, the alternative VNTR single-locus markers are better suited for linkage analyses. The single-locus VNTR markers-simple sequence repeat (SSR) markers-have become the markers of choice by human geneticists (Weissenbach et al., 1992) due to their high level of polymorphism.

Avocado (Persea americana) is a diploid fruit tree with $2 n=24$ chromosomes and a moderate genome size of $883 \mathrm{Mb}$ (Arumuganathan and Earle, 1991). Two types of VNTR markers were applied to avocado: multilocus markers (Lavi et al., 1991) and single-locus markers (Lavi et al., 1994a).

Received for publication 18 Dec. 1995. Accepted for publication 8 Apr. 1996. The cost of publishing this paper was defrayed in part by the payment of page charges. Under postal regulations, this paper therefore must be hereby marked advertisement solely to indicate this fact.

${ }^{1}$ To whom reprint requests should be addressed.
Avocado cultivars are divided into two groups based on their flowering mode: type A, in which each flower is functionally a female in the morning and a male in the following afternoon, and type $\mathrm{B}$, in which each flower is a female in the afternoon and male in the following morning. This flowering dichogamy is rarely absolute and self-pollination often takes place. Thus, fruit may result from either cross- or self-pollination (Bergh, 1977).

Heterozygosity in several organisms has been estimated using DNA fingerprints. Almost all DNA fragments observed in humans, dogs, cats, and wild house sparrow, by hybridization of genomic DNA with minisatellite probes, appear to be heterozygous, as found also in other cross-fertilizing species (Jeffreys et al., 1985b; Wong et al., 1986). On the other hand, most fragments appear to be homozygous in cultivars of rice (Oryza sativa), which is a self-fertilized crop (Dallas, 1988). Heterozygous fragments are usually transmitted in a 1:1 ratio (Dallas, 1988; Jeffreys et al., 1985b). In apple, Nybom and Schaal (1990), using the M13 probe, reported a 1:1 distribution for most but not all minisatellite fragments.

Heterozygosity can be estimated in various ways. Nei (1973) suggested the term heterozygosity or gene diversity (GD) to measure the genetic variation in a population. This estimate is obtained by subtracting from unity the sum of the squared allelic frequencies. Nei and Roychoudhury (1974) concluded that for estimating the average heterozygosity, a large number of loci should be used rather than a large number of individuals per locus. The estimated heterozygosity is very similar to the polymorphism index (Keim et al., 1992) or polymorphism information content (PIC) (Botstein et al., 1980). In soybean, an analysis of seven SSR markers among 26 nonancestral cultivars (Rongwen et al., 1995) suggested a mean GD of 0.74 and 7.3 alleles per locus, while an analysis of 90 RFLPs among 38 cultivars, suggested a mean GD of 0.3 (Keim et al., 1992). Wu and Tanksley (1993) estimated the 


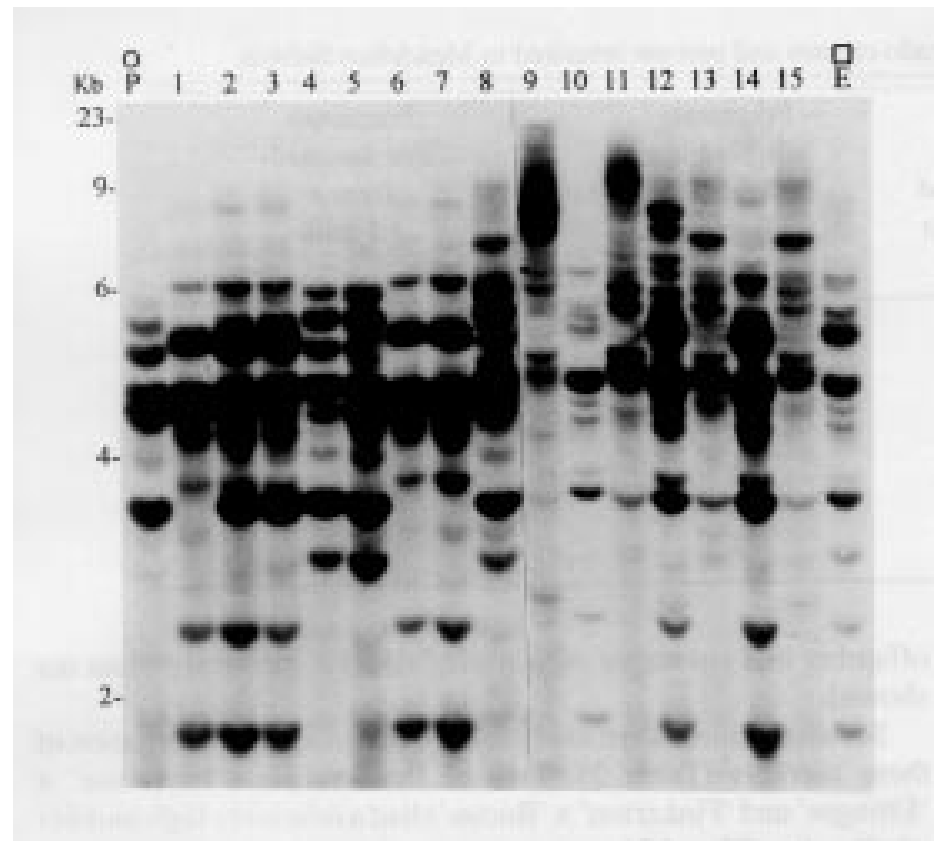

Fig. 1.DNA fingerprints of 15 randomly selected progeny (1 to 15) originating from a cross between 'Pinkerton' (P) and 'Ettinger' (E). DNA was digested with Hinf I and hybridized to probe 22.3. Molecular weights are given in kilobases.

heterozygosity of 18 SSR markers in 20 rice accessions to be 0.79 , which is seven to ten times greater than that estimated using RFLPs.

In this study, heterozygosity and mode of inheritance of minisatellite loci and SSR markers were studied in avocado cultivars.

\section{Materials and Methods}

Plant material. Progeny plots were located at the Akko Experiment Station and the Agricultural Research Organization, Bet Dagan, Israel. Crosses were performed by caging trees under a net, using bees as the pollen vector. The harvested seeds were sown in a nursery and, 1 year later, the seedlings were transplanted into breeding plots (Lavi et al., 1993a). Seven crosses, including 'Pinkerton' x 'Ettinger', 'Pinkerton' $x$ 'Bacon', 'Tova' $x$ 'Sharwil', 'Horshim' x 'Anaheim', 'Pinkerton' x 'N-151-2', 'Benik' $x$ 'Benik', and 'Regina' $x$ 'Regina', were made, and 72, 54, 11, 12, 10, 11, and 10 progenies from these crosses, respectively, were used in the study. These cultivars represent a wide section of commercial cultivars in Israel (it is quite a narrow pool of the avocado native germplasm). DFP patterns were used to confirm parentage of each seedling.

'Bacon', 'Ettinger', 'Horshim', 'Pinkerton', and 'XX102' were assessed by the SSR DNA markers.

DNA isolation. DNA was isolated from very young leaves using the method described by Murray and Thompson (1980), with modifications as described by Lavi et al. (1991). The extraction buffer was modified by using $2 \%$ cetyltrimethyl ammonium bromide (CTAB), $0.1 \mathrm{M}$ Tris- $\mathrm{HCl}$ at $\mathrm{pH}=8,0.02 \mathrm{M}$ ethylenediamine tetra acetic acid (EDTA), $1.4 \mathrm{M} \mathrm{NaCl}$, and 1\% 2-mercaptoethanol. Chloroform extractions were carried out three times and two volumes of precipitation buffer were added to the final aqueous phase. The precipitation buffer was $1 \% \mathrm{CTAB}, 0.05 \mathrm{M}$ Tris- $\mathrm{HCl}$ at $\mathrm{pH}=8,0.01 \mathrm{~m}$ EDTA, and 1\% 2-mercaptoethanol. Nucleic acids were dissolved in $1 \mathrm{M} \mathrm{CsCl}$, precipitated with ethanol, and redissolved in TE (10 mm Tris- $\mathrm{HCl}$ at $\mathrm{pH}=8,1 \mathrm{~mm}$ EDTA). Three additional extractions were made with phenol, phenol-chloroform, and chloroform. The DNA was precipitated with ethanol and dissolved in TE.

DNA fingerprinting $(D F P)$. Ten micrograms of DNA was digested with HinfI restriction endonuclease according to manufacturer's recommendations (New England Biolabs, Beverly, Mass.). Electrophoresis was carried out on a 20-cm-long $0.8 \%$ agarose gel in TBE $(0.045 \mathrm{~m}$ Tris-borate, $0.001 \mathrm{~m} \mathrm{EDTA}$ at $\mathrm{pH}=$ $8.0)$ at $1.5 \mathrm{~V} / \mathrm{cm}$ for $40 \mathrm{~h}$. Gels were Southern blotted onto Hybond $-\mathrm{N}^{+}$membranes (Amersham International, Amersham, U.K.). Lambda Hind III fragments (New England Biolabs) served as size markers.

Membranes were hybridized to the double-stranded probe 22.3, a 2-kb probe that includes probe R18.1 (Haberfeld et al., 1991). Probes were labeled with ${ }^{32} \mathrm{P}-\mathrm{dCTP}$ by random priming (Feinberg and Vogelstein, 1983). Prehybridization and hybridization were carried out at $65^{\circ} \mathrm{C}$ for 3 to $5 \mathrm{~h}$ and $16 \mathrm{~h}$, respectively, in $0.263 \mathrm{M}$ Na-phosphate buffer with 7\% sodium dodecyl sulfate (SDS), $1 \mathrm{~mm}$ EDTA, and $1 \%$ bovine serum albumin (BSA).

Membranes were washed with $0.263 \mathrm{~m} \mathrm{Na-phosphate} \mathrm{and} 1 \%$ SDS for $20 \mathrm{~min}$, then twice with $2 \times$ saline sodium citrate (SSC), and $0.1 \%$ SDS for $20 \mathrm{~min}$ each and twice with $1 \times$ SSC and $0.1 \%$ SDS for $20 \mathrm{~min}$ each. Washes were carried out at $65^{\circ} \mathrm{C}$. Membranes were autoradiographed for 1 to 10 days at $-80^{\circ} \mathrm{C}$ with intensifying screens.

SSR typing. PCR amplifications were performed in a total volume of $10 \mu \mathrm{L}$ containing $30 \mathrm{ng}$ genomic DNA, $1.5 \mathrm{~mm} \mathrm{Mg} \mathrm{Mg}^{2+}$, $0.15 \mu \mathrm{M}$ of each primer, $100 \mu \mathrm{M}$ of each nucleotide, $200 \mathrm{pg} / \mu \mathrm{L}$ BSA, $0.1 \mu \mathrm{L}$ of $3000 \mathrm{Ci} / \mathrm{mmol} \alpha^{32} \mathrm{P}$-dCTP, $1 \times$ Taq buffer (containing $50 \mathrm{~mm}$ Tris- $\mathrm{HCl}$ at $\mathrm{pH}=9,0.1 \%$ Triton $\mathrm{X}-100), 1$ unit of Taq DNA polymerase, and $30 \mu \mathrm{L}$ of mineral oil placed on top of the reaction. The reaction tubes were prewarmed to $95^{\circ} \mathrm{C}$ for $30 \mathrm{~s}$ and the cycles consisted of denaturation at $95^{\circ} \mathrm{C}$ for $15 \mathrm{~s}$ annealing at 45 or $50^{\circ} \mathrm{C}$ (depending on the primers) for $25 \mathrm{~s}$ and extension at $68^{\circ} \mathrm{C}$ for $25 \mathrm{~s}$. Thirty-two cycles were made followed by another extension stage for $2 \mathrm{~min}$. Stop solution was added in the end of the reaction, and $3 \mu \mathrm{L}$ of the reaction was loaded on a DNA-sequencing gel containing $6 \%$ polyacrylamide, $8 \mathrm{~m}$ urea, and $1 \times \mathrm{TBE}$. Electrophoresis was run at $50 \mathrm{~W}$ for 3 to $4 \mathrm{~h}$. Gels were dried and exposed overnight to an X-ray film. SSR loci were defined by the

Table 1. Number of analyzed fragments and number of heterozygous fragments identified using the minisatellite probe 22.3 in 10 avocado parent cultivars.

\begin{tabular}{lcc}
\hline \hline $\begin{array}{l}\text { Parent } \\
\text { cultivar }\end{array}$ & $\begin{array}{c}\text { Analyzed } \\
\text { fragment } \\
\text { no. }\end{array}$ & $\begin{array}{c}\text { Heterozygous } \\
\text { fragment }^{z} \\
\text { no. }(\%)\end{array}$ \\
\hline Pinkerton & 13 & $13(100)$ \\
Ettinger & 10 & $10(100)$ \\
Bacon & 8 & $8(100)$ \\
Regina $^{y}$ & 20 & $18(90)$ \\
Benik $^{y}$ & 18 & $17(94)$ \\
N-151-2 & 7 & $7(100)$ \\
Anaheim & 10 & $10(100)$ \\
Horshim & 6 & $6(100)$ \\
Tova & 16 & $16(100)$ \\
Sharwil & 6 & $6(100)$
\end{tabular}

$\overline{{ }^{2} P a r e n t a l}$ fragment was defined as heterozygous if detected in some of the progeny and not in all the progeny.

'Fragments of 'Regina' and 'Benik' were analyzed in the progeny of selfpollination. In all other cases, fragments were analyzed in the progeny of controlled crosses (see Materials and Methods). 
Table 2. Number of DNA fingerprint fragments of various avocado crosses and percent inherited in Mendelian fashion.

\begin{tabular}{|c|c|c|c|c|c|}
\hline \multirow[b]{2}{*}{ Cross } & \multirow{2}{*}{$\begin{array}{c}\text { Offspring } \\
\text { no. }\end{array}$} & \multirow{2}{*}{$\begin{array}{c}\text { Analyzed } \\
\text { fragment } \\
\text { no. }\end{array}$} & \multirow[t]{2}{*}{$\begin{array}{l}\text { Fragments } \\
\text { inherited in a } \\
\text { Mendelian } \\
\text { fashion } \\
(\%)\end{array}$} & \multicolumn{2}{|c|}{$\begin{array}{c}\text { Fragments } \\
\text { that deviated } \\
\text { from a } \\
1: 1 \text { ratio }\end{array}$} \\
\hline & & & & $P<0.05$ & $P<0.01$ \\
\hline Pinkerton $\mathrm{x}$ Ettinger & 72 & 23 & 64.3 & 9.7 & 26 \\
\hline Pinkerton $\times$ Bacon & 54 & 20 & 85 & 10 & 5 \\
\hline Pinkerton $\times$ N-151-2 & 10 & 20 & 80 & 10 & 10 \\
\hline Horshim x Anaheim & 12 & 16 & 62.5 & 6.25 & 31.25 \\
\hline Tova $\times$ Sharwil & 11 & 22 & 63.7 & 27.2 & 9.1 \\
\hline Regina $x$ Regina & 10 & 20 & 70 & 15 & 15 \\
\hline Benik $x$ Benik & 11 & 18 & 72.3 & 0 & 27.7 \\
\hline
\end{tabular}

nucleotide repeat type: loci that contained AG/TC repeats were defined as $A_{n}$, loci that contained $A / T$ repeats were defined as $A_{n}$, where $\mathrm{n}$ is the number of repeats. Alleles were identified by the analysis of 50 offspring of a cross between the female parent 'Pinkerton' and a pollen donor 'Ettinger'. Average heterozygosity in SSR loci was calculated according to Nei and Roychoudhury (1974): $\mathrm{AH}=1-\sum \mathrm{pi}^{2}$, where $\mathrm{AH}$ is the average heterozygosity and pi is the frequency of the $\mathrm{i}^{\text {th }}$ allele. GD was calculated according to Rongwen et al (1995): GD $=1-\sum \mathrm{pi}^{2}$, where pi is the frequency of the $\mathrm{i}^{\text {th }}$ pattern. Percent heterozygosity was calculated as the proportion of heterozygote genotypes from all tested genotypes.

\section{Results}

Assessment of heterozygosity in avocado, was carried out using DNA fingerprints (obtained by minisatellites), in which usually only one allele was detected, and SSR markers, in which both alleles could be detected in each individual.

Heterozygosity in minisatellite loci. Only DNA fragments that could be reliably and consistently evaluated in each sample were analyzed. DNA fragments ranged between 2 to $22 \mathrm{~kb}$ (Fig. 1). A parental fragment was defined as being in a heterozygous state if detected only in some of the progeny rather than in all the progeny.

The analysis of parental fragments of the cultivars: 'Pinkerton', 'Ettinger', 'Bacon', 'N-151-2', 'Anaheim', 'Horshim', 'Tova', and 'Sharwil' was carried out in progeny of controlled crosses. It was found that all fragments were present in the heterozygous state; heterozygosity was therefore $100 \%$ (Table 1). Fragments of progeny from selfing of 'Regina' and 'Benik' indicated heterozygosity of $90 \%$ and $94 \%$, respectively (Table 1). Two fragments in 'Regina' and two fragments in 'Benik' were defined as being in a heterozygous state based on their presence in nine out of ten offspring and ten out of eleven offspring, respectively (data not shown).

Seven families were analyzed for the mode of inheritance of these markers (Table 2). Two of the families ('Pinkerton' $x$ 'Ettinger' and 'Pinkerton' $x$ 'Bacon') had a relatively high number of offspring (72 and 54, respectively), while the other five families contained only 10 to 12 offspring. Most of the fragments were found to be inherited in a 1:1 ratio. The lowest percentage $(62.5 \%)$ of fragments that inherited in a 1:1 ratio was found in the cross of 'Horshim' $x$ 'Anaheim' and the highest percentage (85\%) was found in the cross of 'Pinkerton' $x$ 'Bacon' (Table 2). Overall, the percentage of fragments that deviated from a 1:1 ratio ranged from $15 \%$ to $37.5 \%$. In most cases, the statistical significance was $P<$ 0.01 and in other cases $P<0.05$ (Table 2). Even in the largest family, 'Pinkerton' $x$ 'Ettinger' (72 progeny), the percentage of fragments inherited in a manner that deviated from a 1:1 ratio was relatively high $(35.7 \%)$.

Heterozygosity level in SSR loci. Of 59 avocado SSR loci analyzed, 29 had $A_{n}$ repeats, 19 had $A_{n}$ repeats, 7 loci had more than one type of repeat, and 4 loci had other types of repeats (Table 3 ). To characterize the alleles, each locus was analyzed in 50 progeny of the cross 'Pinkerton' $x$ 'Ettinger'. The alleles of each parent were assessed based on their mode of inheritance. The alleles of 'Bacon', 'Horshim', and 'XX102' were characterized by comparing them to 'Pinkerton' and 'Ettinger' alleles. The percent heterozygosity of each SSR type found in the five cultivars is presented in Table 4.

The dinucleotide repeat $A_{n}$ and the mononucleotide repeat $A_{n}$ were the most polymorphic SSR loci (of those examined) in avocado and, thus, presented the highest mean number of alleles per locus (4.1 and 3, respectively) and highest heterozygosity (70\% and 67\%, respectively) (Tables 3 and 4$)$. The mean heterozy-

Table 3. Average heterozygosity, gene diversity and number of alleles in various types of simple sequence repeat loci in five avocado cultivars.

\begin{tabular}{lccccc}
\hline \hline $\begin{array}{l}\text { Simple } \\
\text { repeat }\end{array}$ & $\begin{array}{c}\text { Loci } \\
\text { no. }\end{array}$ & $\begin{array}{c}\text { Mean no. } \\
\text { of alleles }\end{array}$ & Range & $\begin{array}{c}\text { Avg } \\
\text { heterozygosity }\end{array}$ & $\begin{array}{c}\text { Gene } \\
\text { diversity }\end{array}$ \\
\hline $\mathrm{AG}_{\mathrm{n}}$ & 29 & 4.1 & $1-8$ & 0.66 & 0.66 \\
$\mathrm{~A}_{\mathrm{n}}^{\mathrm{n}}$ & 19 & 3 & $1-6$ & 0.51 & 0.42 \\
Compound $^{\mathrm{y}}$ & 7 & 2.5 & $1-5$ & 0.50 & 0.56 \\
Others $^{\mathrm{x}}$ & 4 & 2.6 & $1-4$ & 0.51 & 0.55 \\
Total & 59 & 3.4 & $1-8$ & 0.58 & 0.56
\end{tabular}

${ }^{\mathrm{z} S S R}$ loci were defined by the nucleotide repeat type: loci that contained AG/TC repeats were defined as $\mathrm{AG}_{\mathrm{n}}$, loci that contained $\mathrm{A} / \mathrm{T}$ repeats were defined as $\mathrm{A}_{\mathrm{n}}$, where $\mathrm{n}$ is the number of repeats.

${ }^{\mathrm{y}}$ Compound more than one simple repeat in tandem. Example: $\mathrm{A}_{28} \mathrm{AG}_{10}$.

${ }^{\mathrm{x}}$ Others: Simple repeats different from the above. 
Table 4. Percent heterozygosity in five avocado cultivars detected in various simple sequence repeat loci.

\begin{tabular}{lcccccc}
\hline \hline Simple & \multicolumn{5}{c}{ Percent heterozygosity } \\
\cline { 2 - 7 } repeat & Ettinger & Pinkerton & Bacon & Horshim & XX102 & Mean \\
\hline $\mathrm{AG}_{\mathrm{n}}$ & 68 & 68 & 67 & 82 & 63 & 70 \\
$\mathrm{~A}_{\mathrm{n}}^{\mathrm{z}}$ & 65 & 79 & 67 & 60 & 65 & 67 \\
Compound $^{\mathrm{y}}$ & 30 & 30 & 43 & 60 & 33 & 39 \\
Others $^{\mathrm{x}}$ & 40 & 20 & 58 & 60 & 50 & 38 \\
Total & 59 & 62 & 70 & 58 & 62
\end{tabular}

${ }_{\mathrm{z}}^{\mathrm{z} S \mathrm{SR}}$ loci were defined by the nucleotide repeat type: loci that contained AG/TC repeats were defined as $\mathrm{AG}_{\mathrm{n}}$, loci which contained $\mathrm{A} / \mathrm{T}$ repeats were defined as $\mathrm{A}_{\mathrm{n}}$, where $\mathrm{n}$ is the number of repeats.

${ }^{\mathrm{y}}$ Compound more than one simple repeat in tandem. Example: $\mathrm{A}_{28} \mathrm{AG}_{10}$.

${ }^{x}$ Others: Simple repeats different from the above.

gosity in the five cultivars was estimated to be $62 \%$ and varied between 58\% and 70\%. 'Horshim' had the highest level of heterozygosity (Table 4). In summary, the analysis of 59 loci in five cultivars indicated an average of 3.4 alleles per locus and a mean heterozygosity of $62 \%$. Average heterozygosity was calculated for each repeat type and varied between 0.50 to 0.66 , with an average of 0.58 , while gene diversity varied between 0.42 to 0.66 (Table 3 ). An example of two polymorphic loci is presented in Fig. 2. Locus IA061E02 contained seven alleles and locus IA043H11 contained six alleles in the five cultivars.

Fifty progeny of the cross 'Pinkerton' $x$ 'Ettinger' were analyzed for the distribution of alleles at 55 SSR loci. Eighty-five percent of the loci segregated in a Mendelian fashion (1:1). On the contrary, $11 \%$ showed non-Mendelian segregation at $P<0.01$ and $4 \%$ showed non-Mendelian segregation at $P<0.05$.

\section{Discussion}

Two types of DNA markers were used to assess the level of heterozygosity in avocado. One hundred eighty offspring of seven different crosses were typed using multilocus VNTR probes. Heterozygosity in this cross-pollinated crop was estimated by multilocus VNTR markers to be on the average $98 \%$, which is similar to that of humans. The heterozygosity detected by SSR loci analysis was lower than that for the minisatellite loci (62\% vs. 98\%). Microsatellites are shorter than minisatellites; therefore, one might expect fewer alleles due to an unequal crossing overs or replication slippage. Moreover, the multilocus (minisatellite) analysis does not include nonpolymorphic bands present in both parents, thus, possibly overestimating the heterozygosity. Finally, one must consider that the number of alleles in the SSR loci was determined using only five avocado cultivars, while DFP estimation is based on ten.

Heterozygosity at SSR loci was estimated in rice to be $0.79 \mathrm{(Wu}$ and Tanksley, 1993). Gene diversity in soybean varied between 0.52 to 0.95 (Rongwen et al., 1995). These values are higher than the values found in this study for avocado (average heterozygosity 0.58 and gene diversity 0.56 ). These lower values found in avocado may be due to the fact that this avocado analysis was intraspecific while the rice and soybean analyses were interspecific.

In this study, heterozygosity in SSR loci was calculated in two ways (Table 3 ). The two estimates, average heterozygosity (58\%) and percent heterozygosity (62\%), are very similar.

Two other types of markers have been used in avocado: RFLPs (Furnier et al., 1990) and isozymes (Degani et al., 1990). Furnier et al. (1990) analyzed several Persea species and avocado cultivars using two RFLP markers. Most of the trees (60\%) were found to be homozygous at both RFLP loci and the rest were heterozygous for at least one marker (the average heterozygosity was found to be $26 \%$ ). The average level of heterozygosity for five isozyme loci analyzed in seven avocado cultivars was $42 \%$ (calculated on the basis of Degani et al., 1990). RFLP and isozyme markers show low heterozygosity compared to the results of this study. This is due to the high level of polymorphism in VNTR loci compared with RFLPs and isozymes (Lavi et al., 1994a). A low level of selfpollination is probably the cause for the high of heterozygosity in avocado (Lavi et al., 1993b). It is noteworthy that a high level of heterozygosity and significant nonadditive variance components were identified in analysis of several important agricultural traits in avocado (Lavi et al., 1993b).

In the present analysis, most, but not all, of the fragments fit a 1:1 ratio. Similar data were obtained for apple minisatellite loci (Nybom and Schaal, 1990). Almost 30\% of the minisatellite loci (of which $17.7 \%$ was detected using a conservative statistical significance of $P<0.01$ ) and $15 \%$ of the SSR loci did not fit the expected 1:1 ratio. These results could not be explained by small family size as they were obtained using the 72 progeny of 'Pinkerton' $x$ 'Ettinger'. However, they could be explained by linkage of these loci to genes that have adaptation disadvantages. Such deviation from the expected ratio was also detected in avocado in the case of the leucine amino peptidase isozyme locus (Degani et al., 1986).

The results of DNA fingerprint and SSR markers indicated a high degree of heterozygosity in the avocado genome. For breeding purposes, a high degree of heterozygosity among cultivars can

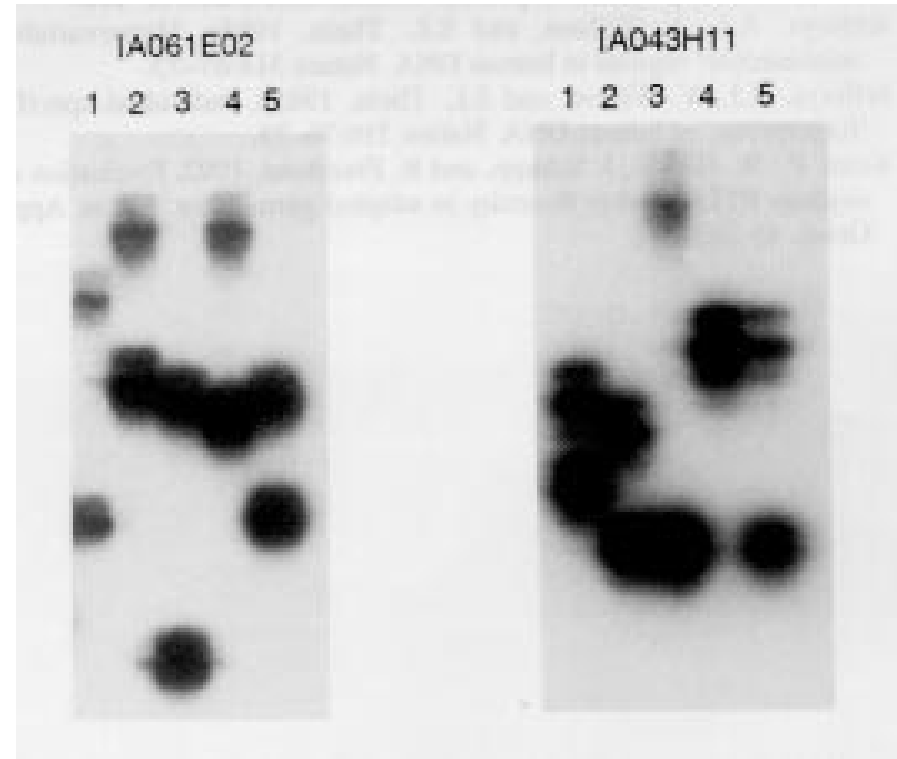

Fig. 2. Two simple sequence repeat markers analysed in five avocado cultivars. Lanes are as follows: 1) 'Ettinger'; 2) 'Pinkerton'; 3) 'Bacon'; 4) ‘Horshim'; and 5) 'XX102'. 
be an advantage, providing a high degree of variation among seedlings that might be exploited by selection. On the other hand, this situation limits the ability of a breeder to predict offspring performance. In this work, two types of VNTR markers were compared as estimators of heterozygosity. In general, the choice of DNA marker type depends on the objective of a research project. DNA minisatellite loci, because of their high heterozygosity, are best suited for fingerprinting or identification purposes. Being multilocus markers, they are not suitable for linkage analysis. SSR markers are heterozygous and, since they are single locus markers, are more suitable for linkage analyses (Lavi et al., 1994b).

\section{Literature Cited}

Adato, A., D. Sharon, U. Lavi, J. Hillel, and S. Gazit. 1995. Application of DNA fingerprints for identification and genetic analyses of mango (Mangifera indica) genotypes. J. Amer. Soc. Hort. Sci. 120:259-264.

Arumuganathan, K., and E.D. Earle. 1991. Nuclear DNA content of some important plant species. Plant Mol. Bio. Rep. 9:208-218.

Bergh, B.O. 1977. Avocado breeding and selection, p. 24-33. In: J.W. Sauls, R.L. Phillips, and L.K. Jackson (eds.). Proc. 1st Intl. Trop. Fruit Short Course: The avocado. Univ. of Florida, Gainesville.

Botstein, D., R.L. White, M. Skolnick, and R.W. Davus. 1980. Construction of genetic linkage map in man using restriction fragment length polymorphisms. Amer. J. Human Genet. 32:314-331.

Dallas, J.F. 1988. Detection of DNA fingerprints of cultivated rice by hybridization with a human minisatellite DNA probe. Proc. Natl. Acad. Sci. USA 85:6831-6835.

Degani, C., A. Goldring, S. Gazit, and U. Lavi. 1986. Genetic selection during the abscission of avocado fruitlets. HortScience 21:1187-1188.

Degani, C., A. Goldring, I. Adato, R. El-Batsri, and S. Gazit. 1990. Pollen parent effect on outcrossing rate, yield, and fruit characteristics of 'Fuerte' avocado. HortScience $25: 471-473$.

Feinberg, A.P. and B. Vogelstein. 1983. A technique for radio labeling DNA restriction endonuclease fragments to high specific activity. Ann. Biochem. 132:6-13.

Furnier, G.H., M.P. Cummings, and M.T. Clegg. 1990. Evolution of the avocados as revealed by DNA restriction site variation. J. Hered. 81:183-188.

Haberfeld, A., A. Cahaner, O. Yoffe, Y. Plotzky, and J. Hillel. 1991. DNA fingerprint of farm animals generated by micro and minisatellite DNA probes. Animal Genet. 22:299-305.

Hillel, J., Y. Plotsky, A. Haberfeld, U. Lavi, A. Cahaner, and A.J. Jeffreys. 1989. DNA fingerprints of poultry. Animal Genet. 20:145-155.

Jeffreys, A.J., V. Wilson, and S.L. Thein. 1985a. Hypervariable 'minisatellite' regions in human DNA. Nature 314:67-73.

Jeffreys, A.J., V. Wilson, and S.L. Thein. 1985b. Individual-specific 'fingerprints' of human DNA. Nature 316:76-79.

Keim, P., W. Beavis, J. Schupp, and R. Freestone. 1992. Evaluation of soybean RFLP marker diversity in adapted germplasm. Theor. Appl. Genet. 85:205-212.
Kuhnlein, U., Y. Dawe, D. Zadworny, and J.S. Javora. 1989. DNA fingerprinting: A tool for determining genetic distances between strains of poultry. Theor. Appl. Genet. 77:669-672.

Lavi, U., J. Hillel, A. Vainstein, E. Lahav, and D. Sharon. 1991. Application of DNA fingerprint for identification and genetic analysis of avocado. J. Amer. Soc. Hort. Sci. 116:1078-1081.

Lavi, U., E. Lahav, C. Degani, and S. Gazit. 1993a. Genetics of skin color, flowering group and anise scent in avocado. J. Hered. 84:82-84.

Lavi, U., E. Lahav, C. Degani, S. Gazit, and J. Hillel. 1993b. Genetic variance components and heritabilities of several avocado traits. J. Amer. Soc. Hort. Sci. 118:400-404.

Lavi, U., M. Akkaya, A. Bhagwat, E. Lahav, and P.B. Cregan. 1994a. Methodology of generation and characteristics of simple sequence repeat DNA markers in avocado (Persea americana M.). Euphytica 80:171-177.

Lavi, U., P.B. Cregan, T. Schaap, and J. Hillel. 1994b. Application of DNA markers for identification and breeding of perennial fruit crops. Plant Breeding Rev. 7:195-226.

Mhameed, S., J. Hillel, E. Lahav, D. Sharon, and U. Lavi. 1995. Genetic association between DNA fingerprint fragments and loci controlling agriculturally important traits in avocado (Persea americana Mill.). Euphytica 81:81-87.

Murray, M.G. and W.F. Thompson. 1980. Rapid isolation of high molecular weight plant DNA. Nucl. Acids Res. 8(13):4321-4325.

Nei, M. 1973. Analysis of gene diversity in subdivided populations. Proc. Natl. Acad. Sci. USA 70:3321-3323.

Nei, M. and A.K. Roychoudhury. 1974. Sampling variances of heterozygosity and genetic distance. Genetics 76:379-390.

Nurnberg, P., L. Roewer, H. Neitzel, K. Sperling, A. Popperl, J. Hundrieser, H. Poche, C. Epplen, H. Zischler, and J.T. Epplen. 1989. DNA fingerprinting with the oligonucleotide probe $(\mathrm{CAC})_{5}$ : Somatic stability and gremline mutation. Human Genet. 84:75-78.

Nybom, H. and B.A. Schaal. 1990. DNA "fingerprints" applied to paternity analysis in apples (Malus $\times$ domestica). Theor. Appl. Genet. 79:763768.

Plotsky, Y., A. Cahaner, A. Haberfeld, U. Lavi, S.J. Lamont, and J. Hillel. 1993. DNA fingerprint bands applied to linkage analysis with quantitative trait loci in chickens. Animal Genet. 24:105-110.

Rongwen, J., M.S. Akkaya, A.A. Bhagwat, U. Lavi, and P.B. Cregan. 1995. The use of microsatellite DNA markers for soybean genotype identification. Theor. Appl. Genet. 90:43-48.

Sharon, D., A. Adato, S. Mhameed, U. Lavi, J. Hillel, M. Gomolca, C. Epplen, and J.T. Epplen. 1995. DNA fingerprints in plants using simplesequence repeat and minisatellite probes. HortScience 30:109-112.

Weissenbach, J., G. Gyapay, C. Dib, A. Virgnal, J. Morissette, P. Millasseau, G. Vaysseix, and M. Lathrop. 1992. A second-generation linkage map of the human genome. Nature 359:794-801.

Wong, Z., V. Wilson, A.J. Jeffreys, and S.L. Thein. 1986. Cloning of a selected fragment from a human DNA 'fingerprint': Isolation of an extremely polymorphic minisatellite. Nucl. Acids Res. 14:4605-4616. Wu, R.S. and S.D. Tanksley. 1993. Abundance, polymorphism and genetic mapping of microsatellites in rice. Mol. Gen. Genet. 241:225-235. 